\title{
Improving Teaching Skills of Pre-teacher Students With Modified Jigsaw on Biology Instructional Methodology Course
}

\author{
Relsas Yogica, Lufri, Rahmadhani Fitri \\ Biology Department \\ Universitas Negeri Padang \\ Padang, West Sumatera, Indonesia \\ relsasyogica.1103992@gmail.com
}

\author{
Arief Muttaqiin \\ Science Education Department \\ Universitas Negeri Padang \\ Padang, West Sumatera, Indonesia \\ ariefmuttaqiin@gmail.com
}

\begin{abstract}
The development of education is strongly influenced by global factors. This global development has a serious impact on the quality of education graduates. Many standards emerge to meet these demands. This responsibility rests with the university, especially the university which produces graduate teacher candidates. Universitas Negeri Padang is one of the Indonesian universities in charge of this. Researches are conducted in order to produce learning innovations, one of which is our research. We have researched classes to improve the teaching abilities of prospective teachers in the Biology Department, Universitas Negeri Padang. We use a modified Jigsaw learning model. This research uses quantitative observation methods for students who take Biology Instructional Methodology course using Teacher Performance Appraisal Instrument 2. Our results were tabulated on average. We collected the initial value before giving treatment. The final score is 84.69by good criteria. The results of this study indicate that the Jigsaw learning model that we modified can improve teaching abilities for prospective teacher students in the Biology Department, Universitas Negeri Padang. This research contributes to increase knowledge and continue to improve the quality of learning in the future.
\end{abstract}

\section{Keywords-Teaching Skills, Modificated Jigsaw, Biology}

\section{INTRODUCTION}

In recent years humans have been preoccupied with the changing times towards the industrial revolution 4.0. Industrial Revolution 4.0 is an era where digitization occurs in all aspects of life, there is a reduction in the role of the human function of doing work. Not only in new approaches, but industry will also be introduced to new methods and new technologies[1].The role of humans is largely replaced by robots through automated systems, due to the development of robotic systems and digitalization[1].New challenge that arises is how an individual prepares himself not to be selected by nature. But the obstacle is whether each individual is able to do that, even worse, are they aware of the challenge? Even education is affected by these changes[2], both formal and informal education[3].

Education has an important role to prepare graduates to have the ability to compete. Education starts from a newborn until he dies, or happens for life[4]. Education can not be separated from the individual self. At least as a social creature that is mutually beneficial to others[5]. People do the education process. Education can be divided into 2 parts, informal education and formal education. Informal education starts from when the baby is born. Informal education does not require official institutions authorized by the government, does not require education and learning tools, does not require special teaching materials and there is no graduation, even many are done outdoors[6].Informal education is a complement to formal education[7].In contrast, formal education requires special institutions, official, clear regulations, clear tools, and there are graduations. Formal education starts from elementary school level to college level. Private education initially did not include formal education until it was authorized by the government to become formal education[8].

The university has been a terminal for every education that humans have gone through since elementary school. Universities have a role to enhance human science from lower levels[9]. Education at universities is more responsible for producing graduates who are competent, have long-term knowledge and the ability to use technology as a source of information[10]. After graduation, each graduate will begin to enter the work environment, which is currently influenced by the challenges of the industrial revolution 4.0, the internet and modern technology[11]. Some universities in Indonesia produce graduates who must be qualified as real teachers. Therefore, they must be equipped with abilities in the field of education and teaching.

The ability of prospective teacher students must be prepared before becoming a real teacher. That ability can be trained during lectures. Universitas Negeri Padang is one of the 10 best universities in Indonesia[12]. In the Biology Department, one of the courses that train prospective teacher students to teach is the Biology Instructional Methodology course. Students practice teaching several times in front of their peers and lecturers. We observed at the beginning of the lecture that students' abilities were still low. The average qualitative assessment of the lecturer said that the teaching ability of students is still not included in the good category. Teachers' ability to teach needs to be assessed because assessing a teacher's ability is part of a teacher's professional assessment[13]. 
Students' abilities can be improved by applying innovation to the learning process. One such innovation is the appropriate model[14][15]. Learning models can improve the quality of learning. Jigsaw is an example of a cooperative learning model. This Jigsaw learning model can improve the quality of the learning process, student motivation, and enjoyable learning experiences [16]. We modified the existing Jigsaw cooperative learning model. The stages of the modified Jigsaw model can be seen in Table I.

TABLE I. MODIFICATED JIGSAW MODEL PHASES

\begin{tabular}{|c|l|}
\hline Phase & \multicolumn{1}{|c|}{ Activities } \\
\hline 1 & Lecture Explanation \\
\hline 2 & Expert Group Preparation \\
\hline 3 & Original Group Discussion \\
\hline 4 & Expert Group Presentation \\
\hline 5 & Group Member's Respond \\
\hline 6 & Lecturer Confirmation \\
\hline 7 & Model Simulation and Discussion \\
\hline
\end{tabular}

The purpose of this study was to determine the effect of the modified Jigsaw learning model on the teaching abilities of prospective teachers in the Biology Department UNIVERSITAS NEGERI PADANG. The influence is seen based on the value of student teaching practices. The research hypothesis is that a modified Jigsaw learning model can significantly improve the teaching abilities of prospective teachers in the Biology DepartmentUNIVERSITAS NEGERI PADANG on Biology Instructional Methodology courses.

\section{METHOD}

\section{A. Types of research}

This research is a classroom action research with several cycles, and two data collection (pre-post). Classroom action research aims to observe and find solutions to problems in the classroom faced by teachers related to improving the quality of learning[17]. The initial data retrieval aims to determine the initial description of students' teaching abilities, and the final data retrieval aims to calculate the student's final grade.

\section{B. Populationand sample}

The study population was all students in the Biology DepartmentUNIVERSITAS NEGERI PADANG. The sampling technique was purposive sampling, where students took part in Biology Instructional Methodology course in the semester.

\section{Instrument}

This study uses a data collection instrument in the form of a questionnaire IPKG 2. The questionnaire is standard, so there is no development stage. Teacher Performance Assessment Instrument (IPKG) 2 is a tool used to evaluate the learning process carried out by teachers during class, in order to create quality learning based on the assessment[18].

\section{Research procedures}

1. Step 1. Research socialization to students. At this stage an introduction to the modified jigsaw model syntax, valuation techniques and instruments is used to assess. This stage is useful to increase student attention[19].

2. Step 2. Conducting research using a modified Jigsaw cooperative learning model.

3. Step 3. Data tabulation.

4. Step 4.Calculate the normality value and the significance value of the data. The significance value is obtained by using a formula: $\mathrm{t}=\mathrm{Md} / \sqrt{ } \sum \mathrm{x}^{2} \mathrm{~d} / \mathrm{N}(\mathrm{N}-1)$

\section{RESULT AND DISCUSSION}

The results of this research are presented in Table 2.

TABLE II.RESULT DATA

\begin{tabular}{|c|c|l|l|}
\hline \multicolumn{2}{|c|}{ Average } & \multicolumn{2}{c|}{ Value } \\
\hline Pre & Post & \multicolumn{1}{|c|}{ Normality Test } & \multicolumn{1}{|c|}{ Significant Test } \\
\hline 63,92 & 84,69 & $\mathrm{~L}_{\mathrm{o}}=0,139$ & $\mathrm{~T}_{\text {count }}=9,195$ \\
& & $\mathrm{~L}_{\mathrm{t}}=0,142$ & $\mathrm{t}_{\text {table }}=1,686$ \\
& $\mathrm{~L}_{\mathrm{o}}<\mathrm{L}_{\mathrm{t}}$ & $\mathrm{t}_{\text {count }}>\mathrm{t}_{\text {table }}$ \\
\hline
\end{tabular}

The results table explains that there is an increase in the average student grades after carrying out practical teaching activities. The increase is known by calculating the average value at the beginning and end of practice. The difference is 20.77. The final value obtained by students is at the qualitative level $\mathrm{A}[20]$. An increase in student scores is normally distributed $\left(\mathrm{L}_{\mathrm{o}}<\mathrm{L}_{\mathrm{t}}\right)$, meaning that the data is distributed into a normal graph in the form of a balanced bell, not leaning right or leaning left[21].After passing the normality test, the research data is not feared to be biased[22].Increase student grades whether significant or not, using a significance test. The result is significant increase in data $\left(\mathrm{t}_{\text {count }}>\mathrm{t}_{\text {table }}\right)$. Significance tests are carried out to calculate how real is the functional relationship between pre-test and post-test values[23].

Analysis of data increase in student grades proves that there is a significant effect of the learning model used on student teaching skills. The intended skills are skills when preparing classes before learning, skills to start learning, skills in the main learning activities, and skills to close learning.

The skills students must have when starting learning are preparing a room, learning tools, learning media and student readiness. By using a modified Jigsaw learning model, students are asked to discuss about the activities carried out by the teacher when starting learning. These are discussed in expert groups and disseminated to the original group.

The skill that prospective teacher students must have at the beginning of learning is the ability to perceive and convey learning objectives. This ability is certainly not easy to have, without the knowledge of that ability. We provide knowledge by integrating it in the learning model. In the final stage, we ask students to practice it. The ability of apperception at the beginning of learning can increase student motivation[24].

Skills in the main learning activities that must be possessed by students are mastery of subject matter, application of learning strategies, utilization of learning resources, implementation of learning involving students, assessment of learning and use of language in teaching. At the end of learning, prospective teacher students are required to be able to 
master the ability to summarize subject matter together with students and plan their next learning. Teachers are also required to be able to conduct assessments in order to measure the achievement of learning objectives, the level of student mastery and the accuracy of teaching methods[18].

All knowledge about teaching skills is included in the modified Jigsaw learning model as material for discussion. Students discuss each subject in the indicators of teaching skills in the expert group, then they explain to their friends in the original group. The aim is that all students can know and understand the skills needed to teach. Sharing information in class is a form of learning that can improve the academic quality of students[25].

The main modification of the Jigsaw model that we applied in this study is the simulation of learning models in teaching practice. We understand education is basically an attempt to mature someone with practice[26].Not only instilling material into students, we also ask students to practice teaching skills they already understand. Teaching practice is an attempt to realize information embedded in the brain into a form of activity that can be assessed, so that information absorption becomes more effective[27]. Teaching practice is also known as microteaching. Microteaching can improve the teaching abilities of prospective teachers[28].

Improvement of the ability of prospective teacher students is due to the implementation of teaching practices. Implementing the practice based on Jigsaw's original syntax is a modification. Improving student ability is not only by modifying the learning model, but can also by using fun methods[29],methods that can enhance student activities[31],project based learning[32], high order thinking learning oeriented[33], and others method.

\section{CONCLUSION}

We have succeeded in proving that a modified type of Jigsaw learning model can improve the teaching abilities of prospective teachers in the Biology DepartmentUNIVERSITAS NEGERI PADANG. The standard used is the teacher performance appraisal instrument 2. Based on the results and discussion it can be concluded that innovation in learning can lead to an increase in the quality of education and the quality of graduates.

\section{ACKNOWLEDGMENT}

This research was carried out because the Indonesian Ministry of Research, Technology and Higher Education. We all the research team would like to express our deepest gratitude. In addition, thanks go to the Research and Community Service Institute, Padang State University, who helped technically prepare the research plan. Next to the staff and chair of the Biology Department who gave permission to carry out this research.

\section{REFERENCES}

[1] A. Benešová, M. Hirman, F. Steiner, and J. Tupa, "Analysis of Education Requirements for Electronics Manufacturing Within Concept
Industry 4.0," in 201841 st International Spring Seminar on Electronics Technology (ISSE), 2018, pp. 1-5.

[2] B. Robandi, E. Kurniati, and R. P. Sari, "Pedagogy In The Era Of Industrial Revolution 4.0," in 8th UPI-UPSI International Conference 2018 (UPI-UPSI 2018), 2019.

[3] R. Yogica, “Tren Pemanfaatan Teknologi Dalam Pembelajaran,” 2019.

[4] I. K. Sudarsana, "Pemikiran Tokoh Pendidikan Dalam Buku Lifelong Learning: Policies, Practices, and Programs (Perspektif Peningkatan Mutu Pendidikan di Indonesia)," J. Penjaminan Mutu, vol. 2, no. 2, pp. 44-53, 2016

[5] M. M. E. I. Bali, "Model Interaksi Sosial dalam Mengelaborasi Keterampilan Sosial," Pedagog. J. Pendidik., vol. 4, no. 2, 2017.

[6] T. Jeffs and J. Ord, Rethinking Outdoor, Experiential and Informal Education: Beyond the Confines. Routledge, 2017.

[7] I. K. Sudarsana, "Membentuk Karakter Anak Sebagai Generasi Penerus Bangsa Melalui Pendidikan Anak Usia Dini," Purwadita J. Agama dan Budaya, vol. 1, no. 1, 2018.

[8] H. Zhou, Q. Liu, J. Tian, and Q. Li, "Private Education and the Tale of Two Sectors," in Private Education in China, Springer, 2018, pp. 1-12.

[9] S. E. Bradforth et al., "University Learning: Improve Undergraduate Science Education," Nat. News, vol. 523, no. 7560, p. 282, 2015.

[10] R. Taconis and P. den Brok, Teachers Creating Context-Based Learning Environments in Science. Springer, 2016.

[11] N. S. Perdana, "Analisis Permintaan dan Penawaran Lulusan SMK dalam Pemenuhan Pasar Tenaga Kerja," Refleks. Edukatika J. Ilm. Kependidikan, vol. 9, no. 2, 2019.

[12] S. Alfari, "10 Universitas Keguruan Negeri Terbaik di Indonesia." https://blog.ruangguru.com/10-universitas-keguruan-negeri-terbaik-diindonesia, 02-May-2019.

[13] W. Kadarko, D. Novita, and R. Delfi, "Pelaksanaan Praktek Mengajar Bagi Guru Peserta Pendidikan Jarak Jauh Yang Tinggal Di Wilayah Terpencil," J. Pendidik., vol. 11, no. 2, pp. 78-87, 2017.

[14] K. Kharil and Y. Yusriati, "Pengembangan Model Analisis Lembar Kerja Siswa untuk Meningkatkan Kemampuan Gramatika Siswa di Kota Medan," Kumpul. Penelit. dan Pengabdi. Dosen, vol. 1, no. 1, 2018.

[15] W. Nuriali, B. Busnawir, H. Samparadja, and L. Ili, "Pengaruh Model Pembelajaran Inkuiri Terbimbing Terhadap Kemampuan Berpikir Kritis Matematika Ditinjau Dari Kemandirian Belajar Siswa SMK," J. Pembelajaran Berpikir Mat., vol. 3, no. 2, 2019.

[16] L. Halimah and V. Sukmayadi, "The Role of" Jigsaw" Method in Enhancing Indonesian Prospective Teachers' Pedagogical Knowledge and Communication Skill.," Int. J. Instr., vol. 12, no. 2, pp. 289-304, 2019.

[17] C. C. Hendricks, History of Action Research in Education. Wiley Online Library, 2019.

[18] D. T. Kependidikan, D. JENDERAL, P. Kependidikan, and D. P. NASIONAL, "Penilaian Kinerja Guru," Jakarta Dep. Pendidik. Nas., 2008.

[19] R. Yogica and H. Helendra, "They do, They Get and They Know; How to Motivate Learner to Upgrade Their Learning Quality," in IOP Conference Series: Materials Science and Engineering, 2018.

[20] A. Irianto, Peraturan Akademik Universitas Negeri Padang, 2015th ed. Padang: Universitas Negeri Padang, 2015.

[21] S. Santoso, Statistik Multivariat: Konsep dan Aplikasi dengan SPSS, 1st ed. Jakarta: Elex Media Komputindo, 2010.

[22] S. Santoso, Structural Equation Modelling: Konsep dan Aplikasi dengan AMOS, 1st ed. Jakarta: Elex Media Komputindo, 2007.

[23] I. Gani and S. Amalia, Alat Analisis Data: Aplikasi Statistik untuk Penelituan Bidang Ekonomi dan Sosial. Penerbit Andi, 2015.

[24] L. H. Puteri, "The Apperception Approach for Stimulating Student Learning Motivation," Int. J. Educ. Train. Learn., vol. 2, no. 1, pp. 7$12,2018$.

[25] M. Sein-Echaluce, F. J. García-Peñalvo, and A. Fidalgo-Blanco, 'Students' Knowledge Sharing to Improve Learning in Academic Engineering Courses," 2016. 
[26] S. Mariyam, R. Triwoelandari, and H. K. Nawawi, "Pengaruh Metode Resitasi Terhadap Motivasi Belajar Pendidikan Agama Islam (PAI) Siswa Kelas VII SMP Pembangunan Bogor," e-Jurnal Mitra Pendidik., vol. 2, no. 11, pp. 1282-1296, 2018.

[27] P. Sari, "Analisis Terhadap Kerucut Pengalaman Edgar Dale dan Keragaman Gaya Belajar untuk Memilih Media yang Tepat dalam Pembelajaran," MUDIR, vol. 1, no. 1, pp. 58-78, 2019.

[28] M. Apling and S. Haryani, "The Analysis of Microteaching in Improving Teaching Skill of Pre-Service Physics Teachers," J. Innov. Sci. Educ., vol. 8, no. 1, 2019.

[29] S. M. Harahap, "Peningkatan Kemampuan Menyimak Melalui Metode Parafrase pada Mahasiswa Semester I Program Studi Pendidikan Bahasa dan Sastra Indonesia Institut Pendidikan Tapanuli Selatan,” J. Educ. Dev., vol. 7, no. 1, p. 32, 2019.

[30] S. M. Harahap, "Peningkatan Kemampuan Membaca Pemahaman
Melalui Metode Global pada Mahasiswa Semester II Program Studi Pendidikan Bahasa dan Sastra Indonesia Institut Pendidikan Tapanuli Selatan," J. Educ. Dev., vol. 7, no. 3, p. 91, 2019.

[31] E. Zubaidah, "Peningkatan Kemampuan Mahasiswa Menulis Cerita Anak Melalui Strategi Menulis Terbimbing," LITERA, vol. 14, no. 1, 2015.

[32] R. S. Wulandari, S. Wahyuni, and F. Syafri, "Peningkatan Kemampuan Mahasiswa dalam Pembelajaran MK Linguistic and Educational Research Melalui Metode Project-Based Learning," Lingua, vol. 12, no. 2, pp. 101-114, 2016

[33] Lufri, R. Fitri, and R. Yogica, "Effectiveness of Concept-Based Learning Model, Drawing and Drill Methods to Improve Student's Ability to Understand Concepts and High-level Thinking in Animal Development Course," in Journal of Physics: Conference Series, 2018. 